\title{
Insertion of English Subject in LL.B Syllabus: A Critical Analysis
}

\author{
${ }^{a}$ Barkat Ali, ${ }^{\text {b }}$ Abdul Quddoos Sial, ${ }^{\text {c }}$ Muhammad Hassan \\ ${ }^{a}$ Assistant Professor, Department of Law, The Islamia University of Bahawalpur, Punjab, Pakistan \\ Email: barkatali27@gmail.com \\ ${ }^{\mathrm{b}}$ Assistant Professor, Department of Law, The Islamia University of Bahawalpur, Punjab, Pakistan \\ Email: aqsials@hotmail.com \\ ${ }^{c} \mathrm{PhD}$ fellow, Faculty of Law, University of Malaya, Malaysia \\ Email: hnsial@gmail.com
}

\begin{tabular}{l}
\hline ARTICLE DETAILS \\
\hline History: \\
Accepted 14 March 2021 \\
Available Online March 2021 \\
\hline Keywords: \\
Pakistan; HECP; English; LL.B; \\
Students \\
JEL Classification: \\
N25, P36 \\
\hline
\end{tabular}

DOI: $10.47067 /$ real.v4i1.117

\begin{abstract}
Since the independence of Pakistan, English has been the language of the whole legal system including the judicial decisions of superior and subordinates courts. Indeed, in general, English language has been playing a pivotal role in order to understand the spirit of legal system, statutes, and judicial verdicts. Therefore, the students of the legal education have been taught additional English subjects in the first three semesters as approved by the Higher Education Commission of Pakistan and endorsed the same by the Pakistan Bar Council with the aiming to enhance their understanding and improvement of English language. However, it is witnessed that the insertion of additional English language courses in the legal education has been criticizing. This research intends to critically explore the significance of English language courses and its liaison with the LL.B program. This treatise adopted a qualitative research method in order to achieve the proposed objective. It carried out an in-depth critical analysis of the insertion of English language courses. Further, face to face interviews of various law students and teachers have been conducted and transcribed accordingly in order to support this research. This study adopted a purposive sampling method because of legal research along with semi-structured interviews.
\end{abstract}

(C) 2021 The authors. Published by SPCRD Global Publishing. This is an open access article under the Creative Commons AttributionNonCommercial 4.0

Corresponding author's email address: barkatali27@gmail.com

\section{Introduction}

The Islamic Republic of Pakistan (Pakistan) was established as an independent state on $14^{\text {th }}$ August 1947. However, it inherited British oriented legal system featured with Anglo-Saxon jurisprudence of law. (Benazir v. Federation, 1988, 488; Rizvi, 1991, 40). At the time of independence, indeed, the existing legal system was decided to be applied to Pakistan. (The Indian Independence Act, 1947, Section 8 (3); The Adoption of the Existing Laws, Order 1947; The Adoption of the Central Acts and Ordinances, Order 1949). Although it was a provisional arrangement, however, such colonial legacy 
continued in the post-colonial era (Munir, 2009, 30-31)

under previous Constitutions (The Constitution 1956, Article 224 (a); The Constitution 1962, Articles 225(1) and The Constitution, 1972, Article, 28o(1) and at present, it is still operational under the Constitution, 1973 of Islamic Republic of Pakistan (The Constitution 1973, Article 268 (1) as well.

In the above context, English has been the language of the whole legal system including laws and judgements since the independence of Pakistan. The same has been the case of all subsequent legislation including the constitution. The similar policy is currently prevailing in the country regarding English language concerning the legislative and administrative matters. Almost all the judgements both in lower and superior courts are delivered in English language as well.

Legal profession has a significant role for carrying on the legal system functioning in a country. The members of the legal profession are educated and trained in the legal educational institutions usually known as law colleges and universities. These institutions in early history have been imparting the legal education in English both for medium of instruction and examination. Subsequently, it became optional either to opt English or Urdu medium for studying the education of Law in term of LLB. However, in 1999 the Islamia University Bahawalpur (IUB) adopted English language for studying the law both in Department of Law and affiliated colleges. Subsequently the other Universities also went on the pattern of English medium of instruction and examination.

Currently LL.B degree program is semester based wherein medium of instruction as well as examination is English except the subjects of Islamic jurisprudence, Islamic Personal Law and Islamic studies (HEC LL.B Syllabus, 2006). For these subjects students have the option to make a choice of English or Urdu language both for teaching and examination. Furthermore for the subject of Legal Drafting a student is bound to follow English as well as Urdu language as medium of instruction and examination (HEC, LL.B Syllabus, 2006). However, such compulsion of pursuing both type of languages is of limited nature only for one Question (HEC, LL.B Syllabus, 2006).

According to the currently prevailing syllabus of LL.B, the students are taught English as subject of 3 credits hours in Semester-I, II and III (HEC LL.B Syllabus, 2006, LAWS-00101, LAWS-00201, LAWS0030). This syllabus is approved by Higher Education Commission of Pakistan (HECP), and has been endorsed by the Legal Education Rules 2015 as amended in 2018. All the Universities in Pakistan have adopted this syllabus for 5 Years Semester based LL.B degree programme being conducted in Department of Law.

The study of the subject of English is intended to provide the students a facility of learning and improving English skills needed for study and understanding of law, and enhancing their capacity building for joining the legal profession. Such the motive behind initiating the semester based five year LLB program which include the subject of English. (Khan, 2013). However, the scope and utilization of teaching English is somewhat suffering criticism in the context of LL.B classes, and thus needs to be analyzed for which this study is undertaken to explore a research question, "Whether the teaching of English as subject in LL.B degree programme is the real need of the students who otherwise made also the major study of this program through English medium"

This research is intended to deliberate the need of teaching of English, and make out the practical impact of such scheme of study of the English learning. While the students are, in fact, studying the subject of Law, and not of English. This study is qualitative based research which employs the descriptive method with an appraisal of the scheme of study having the subject of English for the 
students of law. It eventually, leads us to a result oriented conclusion with suitable suggestions for deciding the future of the subject of English for LL.B degree program as offered in HEC approved syllabus for semester based LL.B degree program.

\section{Legal System \& Legal Education: Liaison and Concerns}

The legal system of the country usually demonstrates the laws made by the legislature and enforced by the executive for the purpose of administration of justice as established by the judiciary. In this, context three main organs of government, namely Parliament, Executive and Judiciary (Constitution, 1973, Articles 50-89, 106-128; 90-105,129-140; 175-212) are the integral part of the legal system. The legislature both at federal and provincial levels, namely he Parliament and the Provincial Assemblies, respectively makes the laws of substantive as well as of procedural nature (Constitution, 1973, Articles 70-77, 89; 1016-117, 128). These laws cover the matters concerning rights and duties of both types of private and public nature.

A student of LL.B during his degree program makes the study of certain types of these laws. Furthermore, he also makes the study of judicial judgements in term of case-law which pertains the facts finding, application of laws and interpretation thereof. Once again, the students come across with these laws and judicial decisions while they join the legal profession either as legal practitioner or judicial officer or judge for the administration of justice.

\section{Legislative and Judicial Language: Law and Policy}

Since, the creation of Pakistan, English language is being used almost for all official purposes particularly for legislation and judicial decision making. This phenomenon is described as that "The British Introduced English in India, and this language still occupies a special position in Pakistan as it is widely used for running the affairs of the government". (Ahmad, 2005).This practice and policy, indeed has been inherited from British legal system. All the laws, rules and regulations are promulgated in English language. Urdu, the national language (Constitution, 1973, Articles, 251), yet is to be declared as official language for all purposes including law making and judicial proceedings.

The Constitution of Pakistan 1973 is the fundamental law of the country providing the mandate for the constitutional democratic governance. It clearly pronounces the law and policy regarding the language used for official and other matters. The constitutional provisions expressly provide that, "The National language of Pakistan is Urdu, and arrangements shall be made for its being used for official and other purposes within fifteen years from the commencing day (Constitution, 1973, Article 251(1)). This Article however, clears further that "the English language may be used for official purposes until arrangements are made for its replacement by Urdu” (Constitution, 1973, Article 251(2)). The similar have been the provisions of the previous Constitutions, 1956 and 1962 (Constitution, 1956, Article 214; Constitution, 1962, Article 215). Though a period of 15 years was anticipated for replacement of English language with the Urdu, a national language, nothing has been appeared in actual form.

The Constitution, 1973 provides a stop gap arrangement for use of English language. Of course, decisive steps should have been taken for the replacement of English language by Urdu. But no such arrangements could not have been made. Why? The answer to such question requires a separate study for which there is no space in this study. However, it is clear from the said provisions that the using of English language for official purposes is justified constitutionally.

The whole judicial proceedings till the final judgement are regulated by the law relevant to the matter in question decided by the court. This law may be both procedural and substantive of public and 
private nature. All these laws are initially drafted and finally promulgated in the English language. We have no single instance of law making in Urdu language since the creation of country till today. So, it seems proper to use the language of the law while applying the law to the facts established in the case, and communicating the opinion as judge in a judicial verdict.

The Code (Civil Procedure 1908 Chapter XX) as well as Criminal (Code of Criminal Procedure 1898 under Chapter XXVI) law requires that the judgments of the court should be pronounced in the language of the court. However, both of these Codes also empower the courts to use English language for writing orders or judgments until a specific bar is created in this regard (Civil Procedure Code, 1908, Sections 137 and Criminal Procedure Code, 1898, Section, 367). The Supreme Court has also held that "Until arrangements have been made for replacement of English, rules requiring the use of English language for the conduct of official business cannot be held to be void" (Shamsuddin v. Registrar, 1967). In another case, the Supreme Court observed that "The study of English language is of particular importance because it is predominantly the court language in the country and is the most widely spoken language in the world" (Pakistan v. Federation, 2007, per Tassaduq Hussain Jillani, J.p.5).

\section{English: Medium of Instruction and Examination for LL.B, Why?}

The students of LL.B program after completing their legal education are entitled to join the legal profession as advocates and pleaders. After the experience of two years as legal practitioner, they may have a chance to be inducted as Magistrate and Judge in the subordinate judiciary. However, after the experience of seven years as advocate someone may be inducted in District judiciary. Such law graduates if qualify otherwise as per requirement of the Constitution, may also be appointed as judge of High Courts, Federal Shariat Court and Supreme Court. These Law graduates may become Attorneys Public Prosecutors at district, provincial and Federal level to assist the subordinate and superior judiciary.

For all these legal professionals the English language is the medium of communication. It is used for pleadings, arguments and the statement of reasons for determination of facts and application of law for final adjudication. Law, having English as its language, is the basic instrument for all these stages in the legal profession. The using of the language of law as it stands on the statute books may, indeed, enable the court to convey their opinion clearly for determining the rights and duties of the parties. So, the using of the language other than of the langue of law will be the translation which may not maintain the originality of the legislation, and thus the justice may not be delivered in true spirit and letter of law.

All professions and social groups, have their own particular pattern of language and expressions used therein. The same is true for the language of legal profession which in context of legal system of Pakistan is English. Though, it might be strange for its being technical, loaded with Latin and antiquated, it has an interesting liaison with legal profession. This is so, because the actual function of law is managed in the language of its own nature built-in in the legal documentation used in legal matters. English language being of dynamic nature has evolved an extraordinarily eclectic vocabulary. So, juridically, it has proved to be an effective and efficient medium of communication worldwide. In law, though, much of the language has been inherited from earlier ages, it has some considerable influences. The celebrated legal historians have observed that "Language is not a mere instrument which we control at will; it controls us.”(Pollock and Maitland, 2010).

So, there is need that such graduates must have a proficiency in English language that is, indeed, the official medium of communication and office working. Therefore, the adoption of the English 
language is justified for the study of law as English is the mother- language of Law as the whole legislation is in English medium. However, it needs to be used properly and with principles of its standard use. So, it becomes important for all perspective members of legal profession to be well versed in English langue regarding spoken, reading and writing. That's why, the medium of instruction and examination is decided to be English for the LL.B study program except the three subjects as discussed above.

\section{English Capacity Building of Students}

For semester based LL.B 5 years program medium of instruction and examination is English, and this is justified for the reasons and factors as discussed above. However, the standard of studentsintake for admission in said LL.B programme is not at the perfect level of English language proficiency. So, the syllabus designers have planned a scheme of study for compensating such deficiency. The syllabus demands the students to study the subject of English for attaining the required level of English proficiency.

According to the currently prevailing syllabus of LL.B the students are taught English as subject of 3 credits hours for three times in different semesters. These subjects are, namely, Functional English, Communication Skills and Technical Writing \& Presentation Skills for the Semester, I, II and III respectively. This syllabus has been developed and approved by National Curriculum Review Committee (NCRC) with the coordination of HECP, and has been endorsed by the Legal Education Rules 2015 as amended in 2018.

The study of the subject of English is intended to provide the students a facility of learning and improving English skills needed for study of law, and enhancing their capacity building for joining the legal profession. Ahmad is of view that "Lawyers who do not have the required competence in English face problems when exposed to professional tasks" (Ahmad, 2005, 5). The possibility of achieving such competency within the given framework of LL.B scheme of study, is appreciated analytically under these lines.

\section{English Learning: Prospective and Problems}

The nature and contents of legal language are different from other languages. This difference is because of its classic use of words. So, there is disagreement on the linguistic status of legalese (language of law) among legal circles and language academics. It is argued that the legalese is a dialect of his own (Berk-Seligion, 2002), and is a statement which encompasses within it the social, financial and moral implications associated with the profession of law. (Khan, 2013, 262).

The use of Legal English in Pakistan, mainly focuses two major aspects, namely the writing and the speaking of English. In the early history of legal profession in Pakistan, the main issue was in written English. The trend of written legal English learning took the momentum due to early litigation concerning Settlement and Revenue matters, and this phenomenon started since the creation of Pakistan in 1947.Whereas as per view of Khan, et al spoken legal English developed with the new generation of lawyers in early history of the profession (Khan, 2013, 262).

For learning the language four skills are very important for language learner. These skills are namely, listening, reading, speaking and writing. It is not possible for them to have the proper understanding of English language without grasping these four language skills. In a language course the proficiency in these four skills, is the target area contributing toward one another. All these skills contribute reciprocally to each other in their attainment. Among these, listening and reading are 
named as receptive skills while speaking and writing are termed as the productive skills. (Khan, 2013).

The use of English as “...language for professional purposes saw the development of ESP which helped a lot in streamlining the targeted goals ascribed to one profession. ESP stands for English for Specific Purposes". (Khan, 2013). The scope of ESP standard coves the purposes of English learning concerning the field of academic, occupational, science and technology, business and economics, and social sciences. (Khan, 2013, 261-62). In an ESP course situation, professional settings determine the target needs. In learning English, simply words are not enough, it is the situation, which maters for good learning. It hold good equally for listening, speaking, reading and writing as well. (Khan, 2013, 263).

The present course designed for English teaching seems not to be in line with the standard guidelines of ESP. The study shows that all skills of English language have not been designed sufficiently for the learners. The course is not fully focused on the all four language skills with the objective to address the professional needs of LL.B students. The requirements of English language learning for these students is different from simple English.

The Students of law like other students of any professional subject develop a particular state of mind in due course of learning. All professions are supposed to introduce a considerable amount of terminologies for their professionals in the language concerned for its readers. Hence by the passage of time law students have a distinguished learning of listening, speaking, reading and writing configuration for the legal profession. Their sense of learning attracts required vocabulary matching their professional demand. In this context, the LL.B Students of concerned classes were interviewed and they responded that while they have a specific pattern of developing professional intellect, they are suffering various difficulties in learning English language which is mostly designed either for literature or linguistic learnings. (Students' Interview, 2021).Moreover, learning law for professional ambition keeps strong in the mind of students. But medium of instruction is innocently taken as an intervening hurdle rather an additional obstacle in the way of reaching the goal. The judgment pronounced by superior courts directing for translation of the body of law in Urdu, (Muhammad v. Government 2015) has substantiate students' indolence. (Students Interview, 2021).

Furthermore, student community in the subject of law at all level is facing difficulties actually inflicting a huge loss in obtaining professional confidence in learning legal propositions. Here it is necessary to understand that student community learning law in English is challenged with two frontages. Simply failing in its effort to cross the barrier of non-native medium of understanding, the student stands dishearten with the image of incapacity to learn law which is incorrect perception. Outburst of such perception at the final stage of studies inflicts a huge loss of confidence thrashing the opening of the career in law. (Students' Interview, 2021).

The research denotes as reflected in Teachers' Interview (2021) that the language course is not developed regarding the future needs of legal profession. The ESP guidelines, if followed, may help to enrich the final product of LLB graduates in English context. A well-equipped English Language Library plays important role for the English learners. The same is the need of the Law classes. The Class room is the fundamental platform for learning activities Class room management comes within the scope of learning legal English. This factor may possibly be effective in English language learning efficiently. The quality of learning skills is based on classroom activity.

Students' Interview (2021) demonstrates that the teaching English is not the real need of the 
students who otherwise made also the major study of this program through English medium. As for the relevance of learning English language for the sake of having acquaintance over the literature produced in English, it is not as demanding as to expand its volume more than main subjects of law. The need may be to the extent of general familiarity and access up to required level. Increasing the volume of additional responsibility of professional student seems unjustified. The concentration should chiefly continue with the professional subjects.

Traditionally, English language as used for law classes all over the world carries peculiar terminologies of law accompanied by static expression and composed convolution. Such usage of traditionalist terminology serves dual purpose like comprehensive theme of the text along with unalterable designing of the documentation. These constraints are not coming to an end rather have to take as many twists as capability of the critic can exhibit. Resolution of these issues demands substantive reliance of students on their national language which should be intrinsically founded in learning system. Concept of learning and mode of intake and processed delivery of thought is predominantly interconnected with common sense grooming within the natural environment of individual in which he lives and learns. So, keeping in view these issues, some Law Students as well as Teachers concerned are of view that the medium of instruction and examination instead of English, should be the national language. (Teachers', Interview, 2021; Students' Interview, 2021).

It is the general observation of the authors being the teacher of law classes that the students in the course of learning are focusing only the career and mistakenly overlook the medium and make mistakes in writing and speaking English. But they are generally unaware of their mistakes. When they speak in English, they utter the wrong pronunciation and the wrong choice of words. Erroneous speaking sparks joking environment involving every audience in class for disheartening comments.

\section{Conclusion}

The study shows on the basis of analysis that it's needless to engage the law students for studying additional English language courses, which have no relevance with the legal language and education. Although, the students of law have also been studied 54 subjects out of 58 in English language, and it provides an ample opportunity to enhance and improve their English language for practicing legal profession. Indeed, Urdu language deserves more attention, as requires the constitution of Pakistan under Article 251, to become a part of LL.B syllabus. It will conceivably assist the law graduates better to understand the legal matters being addressed by them either as judge or lawyer in practical field of legal profession.

\section{References}

Ahmad, N. (2005). Legal English: A case for ESP. PhD diss., Bahauddin Zakriya University, Multan, Pakistan.

Benazir Bhutto v. Federation of Pakistan [1988] PLD SC 416.

Berk-Seligson, S. (2002). The Bilingual Courtroom: Court Interpretations in the

Judicial Process. Chicago: The University of Chicago Press

Higher Education Commission of Pakistan, LLB Syllabus, 2006.

Muhammad Kowkab Iqbal v. Government of Pakistan [2015] PLD SC 1210.

Munir, Muhammad. (2009). Precedent in Pakistani Legal System. PhD diss., University of Karachi, Pakistan.

Pakistan Bar Council v. Federation of Pakistan [2007] PLD SC 394.

Pollock, Sir, F. and Maitland Frederic, W. (2010). The History of English Law before 
the Time of Edward I. 2nd edition, (Indianapolis: Liberty Fund,). Vol. 1.

Rizvi, Syed Iqbal Hadi. (1991) Public Interest Litigation: Liberty and Justice for All.

Delhi Renaissance,.

Shamsuddin Ahmad v. Registrar High Court of East Pakistan [1967] PLD SC 501.

Students' Interview, (2021). Interviews of Students of Department of Law, Faculty of

Law, the Islamia University of Bahawalpur, Pakistan, March, 29, 2021.

Khan Zeshan Ahmed, Shah, Syed Kazim, Khan Raasheda Asmat and Khan

Rakhshanda Asmat. (2013). Designing an English Language Course: A Case Study of LLB (H) Students at Govt. College University Faisalabad-Pakistan. Interdisciplinary Journal of Contemporary Research in Business Copy Right, Vol.4, No. 11. (259-286)

Teachers. (2021). Interviews of teachers of Department of Law, Faculty of Law, the Islamia University of Bahawalpur, Pakistan, March, 29, 2021.

The Constitution of Islamic Republic of Pakistan, 1973.

The Constitution of Islamic Republic of Pakistan, 1956.

The Constitution of Islamic Republic of Pakistan, 1962.

The Code of Civil Procedure, 1908.

The Code of Criminal Procedure, 1898.

The Indian Independence Act, 1947.

The Adoption of the Existing Laws, Order 1947.

The Adoption of the Central Acts and Ordinances, Order, 1949.

The Legal Education Rules, 2015. 